Volume 1, Number 1, 2015

\title{
The Method of Signal Processing when Measuring Non-stationary Values
}

\author{
Myroslav Tykhan ${ }^{*}$, Orest Ivakhiv, Vasyl Teslyuk \\ Lviv Polytechnic National University, S. Bandera Str., 12, Lviv, 79013, Ukraine \\ Received: April 22, 2015. Revised: April 27, 2015. Accepted: June 03, 2015.
}

C 2015 The Authors. Published by Lviv Polytechnic National University.

\begin{abstract}
Nowadays the problem of quick-changing non-stationary values measurement is extremely actual in various modern technical systems (parameters control of engine combustion chamber, testing of aerospace complex products, scientific researches etc.). There are sufficiently effective ways of such measurement. However, increase in the speed of such methods is needed urgently. The attempt of finding the new approach to the problem of sensor output signal processing when measuring non-stationary values using the example of non-stationary pressure measurement by piezoresistive sensors is presented. Piezoresistive sensors of diaphragm type are widely used in pressure measurement in the high-speed automatic systems.
\end{abstract}

Keywords: measurement; non-stationary; pressure; real time; processing; average; signal; sensor.

\section{Theoretical aspects}

The problem of quick-changing non-stationary values measurement is extremely actual in various modern technical systems (parameters control of engine combustion chamber, testing of aerospace complex products, scientific researches etc.) $[1,2]$. Now, there are sufficiently effective ways of such measurement $[3,4]$. However, increase in the speed of such methods is needed urgently.

The attempt of finding the new approach to the problem of sensor output signal processing when measuring nonstationary values using the example of non-stationary pressure measurement by piezoresistive sensors is presented.

Piezoresistive sensors of diaphragm type are widely used in pressure measurement in the high-speed automatic systems $[5,6]$.

The measurement of non-stationary pressure conversion is performed by sensors described by the Volterra integral equation, or involution integral [7]

$$
U(t)=\int_{0}^{t} g(t, \tau) \cdot p(\tau) d \tau
$$

where $g(t, \tau)$ - impulse transient response; $U(t)$ - sensor output signal; $p(t)$ - measuring pressure (input signal). For the equation (1), let us assume that $g(t, \tau) \neq 0, \ddot{g}_{t}(t, \tau)$ and $\ddot{U}(t)$ is real and unceasing. These requirements for sensors and physical signal are unconditional.

Due to physical specialities of the piezoresistive sensors, the equation (1) in more apparent kind is

$$
U(t)=k \cdot \int_{0}^{t} e^{-\beta(t-\tau)} p(\tau) \sin \left(\eta_{0} \cdot(t-\tau)\right) d \tau,
$$

where $\beta$-damping coefficient of diaphragms oscillation; $\eta_{0}$ - natural frequency of its own oscillation; $k$ - static coefficient of sensors conversation.

\footnotetext{
* Corresponding author. Email address: tykhanm@ukr.net
} 
At measuring the dynamic values in the real time, one should have the following equation

$$
p(t)=F^{-1}(U(t))
$$

where $F^{-1}$ - operator, which is inverse to the sensors conversation function.

At measuring the dynamic values, the procedure (3) is called restoration of input signal [7].

It is shown [3] that the equation of the (3) type could be obtained by the double equation differentiation (2), is

$$
p(t)=\frac{\ddot{U}(t)+2 \cdot \beta \cdot \dot{U}(t)+\left(\eta_{0}{ }^{2}+\beta^{2}\right) \cdot U(t)}{k \cdot \eta_{0}} .
$$

So, to restore the input signal (pressure $p(t)$ ) one should have derivatives of the input signal sensor. But because of existence of static error $\delta(t)$, which is in general the stochastic process, the signal $U(t)$ differs from real one and its direct differentiation becomes the incorrect procedure [7].

On the other hand, integral equation (2) can be solved by Fourier transform [7].

Whereas the real sensor input signal $U_{p}(t)$ is obtained with some error $\delta(t)$, it can be written as

$$
U_{p}(t)=U_{0}(t)+\delta(t)=k \cdot \int_{0}^{t} e^{-\beta(t-\tau)} p(\tau) \sin \left(\eta_{0} \cdot(t-\tau)\right) d \tau+\delta(t),
$$

where $U_{0}(t)$ - the real value of the input signal.

Using the Fourier transformation we have

$$
p(t)=\frac{1}{2 \pi} \int_{0}^{\infty} P_{0}(\omega) \exp (j t \omega) d \omega+\frac{1}{2 \pi} \int_{0}^{\infty} \frac{\Delta(\omega)}{G(\omega)} \exp (j t \omega) d \omega,
$$

where $P_{0}(\omega)$ - Fourier transformation of the real value of input signal, $G(\omega)$ and $\Delta(\omega)$ - spectrum of transient function and error function $\delta(t)$.

The second summand in the equation (6) is an error of the accurate equation solution (5) with approximate left part. As it was mentioned, the error $\delta(t)$ in general is stochastic process, that's why dispersion of the task solution is

$$
\sigma_{\delta}^{2}=\frac{1}{2 \pi} \int_{0}^{\infty} \frac{|\Delta(\omega)|^{2}}{|G(\omega)|^{2}} d \omega
$$

where $|\Delta(\omega)|^{2}-$ spectral consistency of power error.

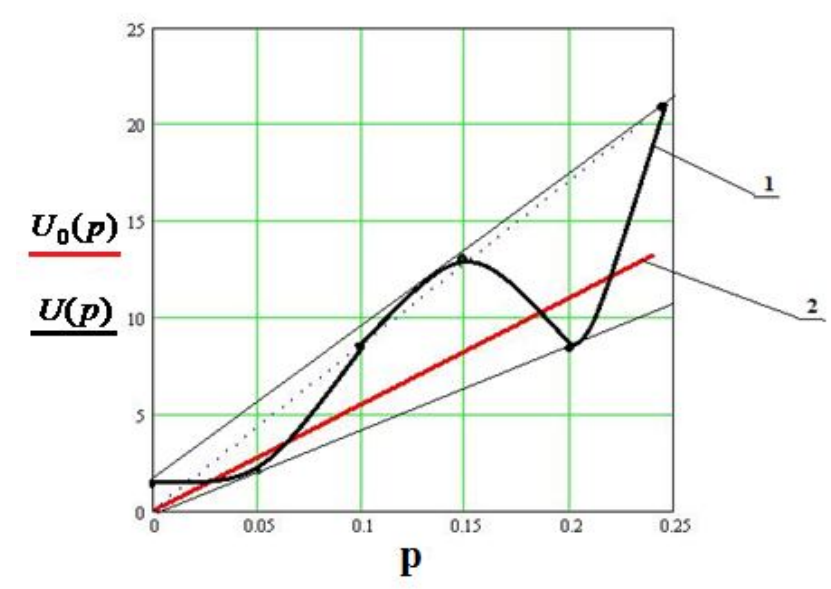

Fig. 1. Output pressure sensor signal at the static measurement

Whereas if $\omega \rightarrow \infty$ the spectral consistency $G(\omega) \rightarrow 0$, and $|\Delta(\omega)|^{2}$ tends to the finite limit or zero (if $\delta(t)$ contains or does not contain the white noise component), then as the result of stochastic nature $\delta(t)$ the dispersion of the equation solution restoration of input signal will be infinite or unacceptably large. So, the integral mismatch (7) is predefined by existence in the input signal of some high-frequency component. So, if it was possible to "damp or smoothen" the high-frequency components, then the task solution restoration of input signal could be persistent. For this purpose, the input signal is previously worked out. One of the most effective ways of the input signal processing is wavelet transformation [4]. However, existing delay by wavelet processing can limit the method application, because nowadays the quick-changing pressure measurement is necessary in the real time during milliseconds. 
To develop some faster way of processing the sensor input signal, first of all let's analyze the speciality of error appearance at static pressure measurement.

In the most general case the sensor is characterized as scrambled type of static error appearance, especially additive-multiplicative, see Fig. 1 (on Fig. 1: the curve 1 shows the real sensor input signal $U(p)$, curve $2-$ the standard signal $\left.U_{0}(p)\right)$.

Obtained values of input signal are as if scattered (are varying) relatively to standard signal. Such situation exists because it is known from practical ecperience that within the limit values the error appears mainly by normal, seldom equable rule.

With error of only additive or only multiplicative type we can get the simplified variant of general case.

Described nature of the static error manifestation at dynamic pressure measurement will also be embodied in the fact that input sensor signal has some "superposition" of waved nature. This "superposition" is the feature of static error in dynamic mode. Herewith the frequency of "superposition" is equal to the frequency of reading the output signal during its analog-to-numeric conversion. Obviously, such fluctuating deviations of the results with the nominal value are the same high-frequency component that leads to incorrect procedure of input signal reclamation.

From the graphical input signal interpretation (Fig. 1), it is obvious that by average value signal determination (as a result of measurements on every reading interval), we get smoothing of "superposition" of waved nature (Fig. 2, a), and with further repeating average procedure, we get better results (Fig. 2, b). Whereas an additive component of static error can be corrected at the sensor calibration step, after some average procedure repeating we should get the processed signal (Fig. 2, c).

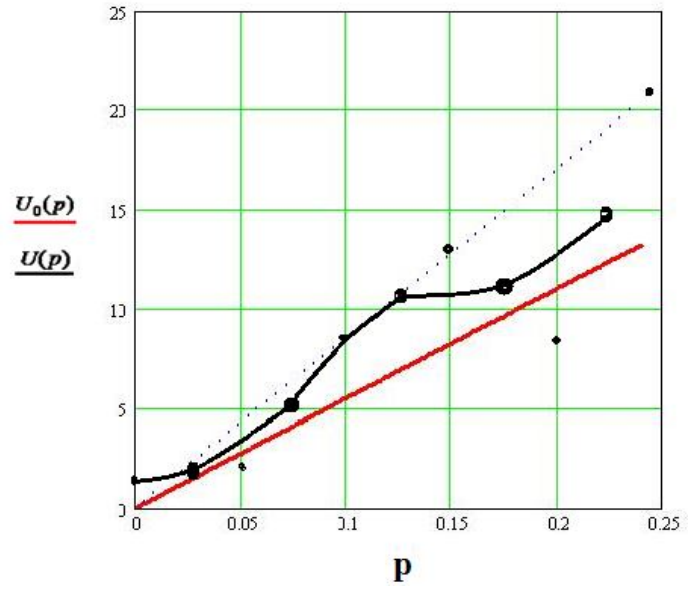

a

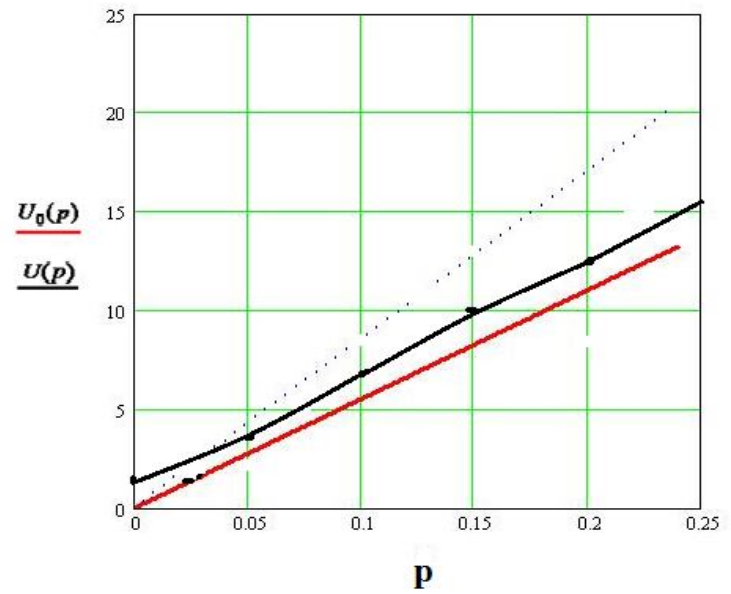

b

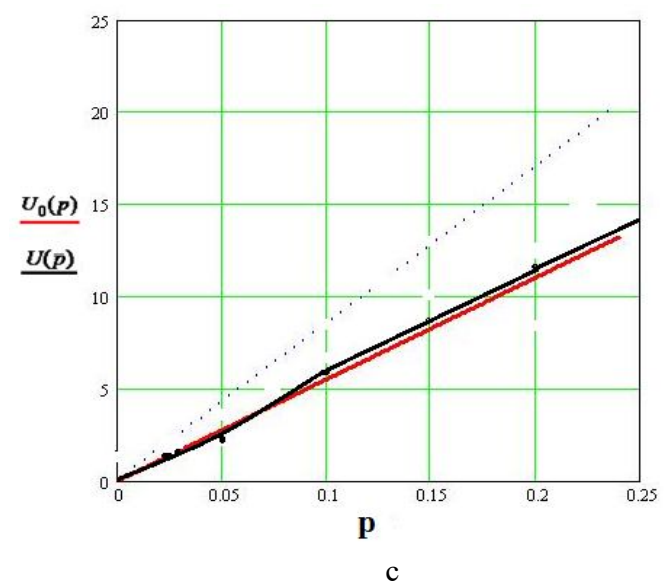

Fig. 2. Smoothened output sensor signal (a), and output sensor signal after repeated procedures of averaging (b and c) 
So, the average interval procedure of output signal gives the signal that does not consist of highfrequency superposition. And it is also obvious that even repeated averaging will occur more faster than working the signal out with waved transformation which provides direct, and after that back signal transforms $U(t)$ [4], by formulas

$$
\begin{gathered}
C_{u}(n, m)=\sum_{m=1}^{\infty} \sum_{n=1}^{\infty} U(t) a^{-m / 2} \psi\left(a^{-m} t-n\right) d t \\
\widetilde{U}(t)=K_{\psi} \sum_{m=1}^{\infty} \sum_{n=1}^{\infty} C_{u}(m, n) a^{-m / 2} \psi\left(a^{-m} t-n\right) d t,
\end{gathered}
$$

where $m, n \in Z ; Z$ - set of real numbers, $a$ - scale parameter; $\psi\left(a^{-m} t-n\right)$ - basis function; $K_{\psi}$ - constant that is defined by basic function.

Herewith, as it is known [9], within each procedure, the scalability and displacement of basis function occur, by which some time is wasted. In addition, for waved transformation, the basic function should be chosen rationally and restriction of appropriate sum members of direct and back discrete transformation should be justified.

It should be emphasized that described averaging interval procedure has no way to remove the dynamic sensor error, which has other immanent nature and does not have influence on correctness of input signal restoration.

\section{Method demonstration}

Let's demonstrate the efficiency of method in example of task of input signal restoration. Let the sensor measure the pressure $p(t)$ in the form of single jump (Fig. 3). It will be ideal if output sensor signal may be its transition function $U_{0}(t)$ (Fig. 3). To come closer to reality, let us distort the function $U_{0}(t)$ by random noise, so that we can interpret the real output signal $U_{p}(t)$ (Fig. 3).

After averaging of signal $U_{p}(t)$ we can get the smoothed signal $U_{y}(t)$ (Fig. 4).

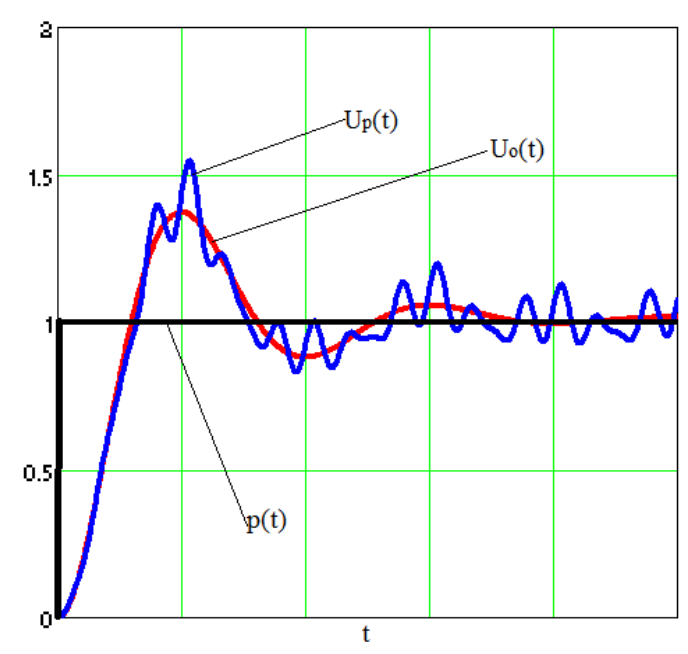

Fig. 3. Measured and appropriate output sensor signal

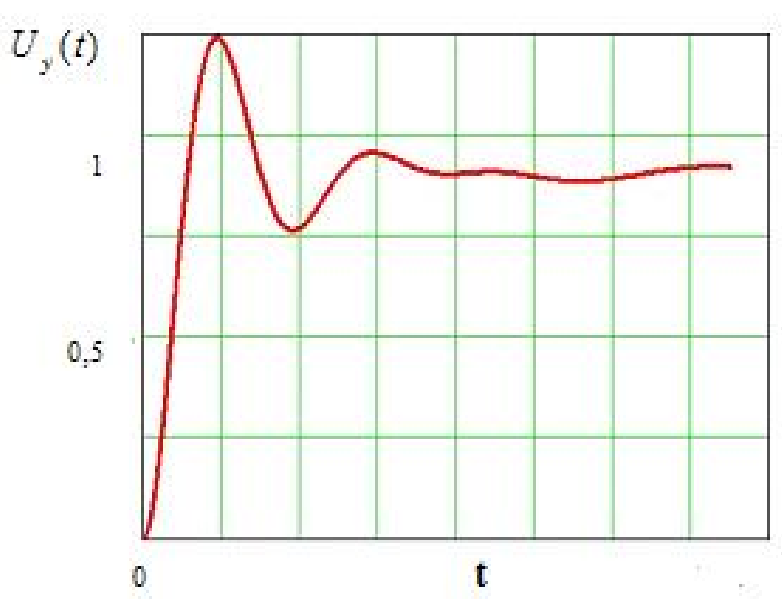

Fig. 4. Output signal sensor after triple interval averaging

After double differentiation of $U_{y}(t)$ and sibstutition of the received values $U_{y}(t), U_{y}^{\prime}(t)$ and $U_{y}^{\prime \prime}(t)$ in (4) we can get a restored input signal $\bar{p}(t)$ (Fig. 5). 
We can surely say that maximum relative error of restored signal $\delta(t)=(p(t)-\bar{p}(t)) / p(t) \times 100 \%$ is $0,11 \%$ (Fig. 6).

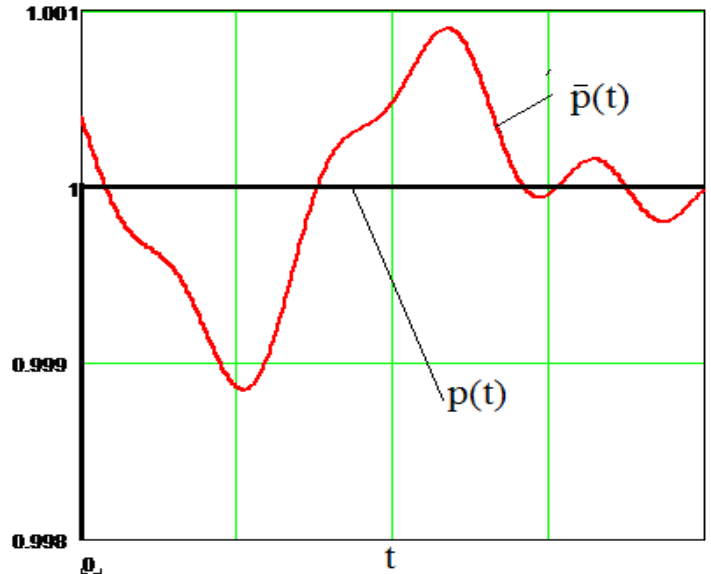

Fig. 5. Restored input signal $\bar{p}(t)$ by the method

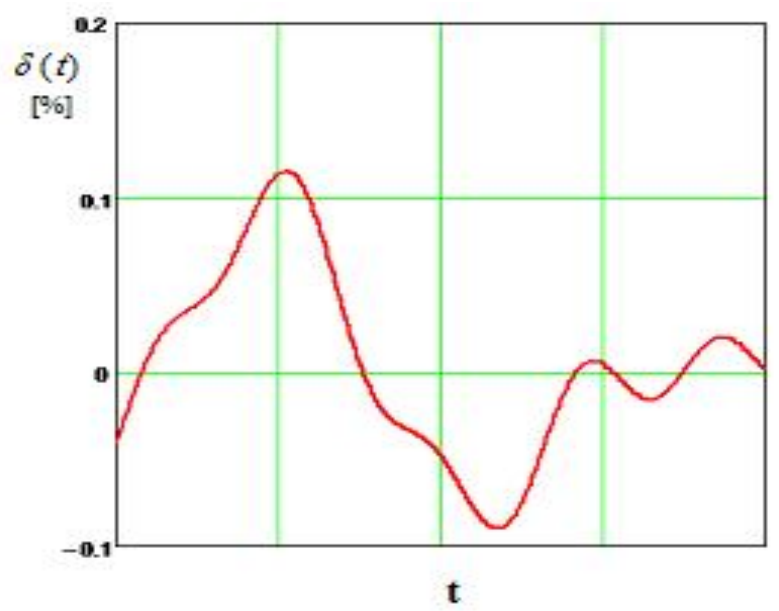

Fig. 6. Relative error of input sensor signal restoration

of interval averaging output signal differentiation

Thereby, the results of modelling show that numerical differentiation of real measured signal, which is processed by interval averaging method, gives an accurate result with error that mostly is smaller than static sensor error.

\section{Conclusion}

Considering the speed of procedure response of averaging the measuring interval signals by real hardware (for example, interface module of L-CARD E 14-14- type [8]), the non-stationary pressure in the real time could be the described method.

\section{References}

[1] Sokolov L. V. An analysis of increasing requirements of micromechanics sensors and MEMS. Sensors and systems / L. V. Sokolov № 6. - 2005. - P. 41-43. (in Russian).

[2] Mokrov E. A. The base system model of new generation of thin films piezoresistive sensors for a rocket and aviation technique // Sensors and systems / E. A. Mokrov, E. M. Belozubov. - № 6. - 2005. - P. 10-14. (in Russian).

[3] Tykhan M. The method of measuring of dynamic pressure / M. Tykhan // Measuring technique and metrology: Bulletin of the National University "Lviv polytechnic". - № 67. - 2007. - P. 55-60. (in Ukrainian).

[4] Tykhan M. Measuring of non-stationary pressure in real-time / M. Tykhan // Bulletin of National Technical University of Ukraine "Kyiv Polytechnic Institute”. Series Instrument Making. - Kyiv. - 2012. - № 43. - P. 72-80. (in Ukrainian).

[5] Mokrov E. A. NII of the physical measuring: 45 year in a space instrument making / E. A. Mokrov // Sensors and systems. -№ 9. - 2005. P. 2-3. (in Russian).

[6] Markelov I. G. Complex of pressure sensors for exploitation on the objects of nuclear energy / I. G. Markelov // Sensors \& Systems. - 2000. - № 11. - 12. - P. 24-25. (in Russian).

[7] Vasylenko G. I. Theory of restoration of signals: About reduction to the ideal device in physics and technique / G. I. Vasylenko. - Moskow : Sov. radio, 1979. - P. 272. (in Russian).

[8] Tykhan M. O. System of measuring non-stationary pressure in real-time by using of interface module type of L-CARD / M. O. Tykhan // The Industrial measuring, control, automation, diagnostics. - Kyiv. - 2008. - № 1. - P. 36-37. (in Ukrainian).

[9] Chui K. Introduction to wawelets / K. Chui. - Moskow : Mir, 2001. - 412 p. (in Russian). 


\title{
Метод опрацювання сигналів при вимірюванні нестаціонарних величин
}

\author{
Мирослав Тихан, Орест Івахів, Василь Теслюк \\ Національний університет “Львівська політехніка”, вул. С. Бандери, 12, Львів, 79013, Україна
}

\begin{abstract}
Анотація
У багатьох сучасних технічних системах (контроль параметрів у камерах згорання двигунів, відпрацювання виробів аерокосмічного комплексу, наукові дослідження тощо) вкрай актуальною $є$ проблема вимірювання швидкозмінних нестаціонарних величин у реальному, чи близько до цього, часі. Сьогодні існують достатньо ефективні способи таких вимірювань. Однак підвищення швидкодії таких способів $\epsilon$ нагальною потребою. У цій роботі робиться спроба нового підходу до проблеми опрацювання вихідних сигналів сенсорів під час вимірювання нестаціонарних величин на прикладі вимірювання нестаціонарного тиску тензорезистивними сенсорами. Для вимірювання тиску у швидкодіючих системах автоматики широко використовуються тензорезистивні сенсори мембранного типу.
\end{abstract}

Ключові слова: вимірювання; нестаціонарний; тиск; реальний час; опрацювання; усереднення; сигнал; сенсор. 